\title{
Design, synthesis, crystal structure, biological evaluation and molecular docking studies of carbazole-arylpiperazine derivatives
}

\author{
Wei Xu ${ }^{a, 1}$, Junjun Huang ${ }^{b, 1}$, Binhao Shao ${ }^{b}$, Xingjie Xu ${ }^{b}$, Renwang Jiang ${ }^{a,{ }^{*}}, \mathrm{Mu}$ \\ Yuan $^{b, *}$, \\ ${ }^{\text {a }}$ School of pharmaceutical sciences, Jinan University, Guangzhou 510632, China \\ ${ }^{\mathrm{b}}$ Pharmaceutical Research Center, Guangzhou Medical University, 195\# Dongfengxi \\ Road, Guangzhou 510182, China \\ Corresponding author. Tel./fax: +86 0208134 0727. E-mail address: \\ mryuanmu838@sina.com (M. Yuan); rwjiang2008@126.com (R. Jiang) \\ ${ }^{1}$ They contributed equally to this work.
}

\begin{abstract}
Subtype-selective $\alpha_{1}$-adrenoceptor (AR) antagonists display optimum therapeutic efficacies for the treatment of benign prostatic hyperplasia (BPH). In this study, we designed and synthesized novel carbazole-arylpiperazines derivatives (1 and $\mathbf{2})$ on the basis of the proposed pharmacophore model for $\alpha_{1}$-AR antagonists. Structural properties were investigated using single-crystal X-ray diffraction analysis. Comparison of crystal structures with ligand-based pharmacophore models revealed that the two agents may possess antagonistic effects on $\alpha_{1 \mathrm{D}}$ subtype. Tissue functional assay in vitro showed that compound $\mathbf{2}$ exerted strong antagonistic activity on $\alpha_{1 \mathrm{~B}}-\mathrm{AR}\left(\mathrm{pA}_{2}\right.$ 7.13) with a poor selectivity for $\alpha_{1 \mathrm{~A}}$ and $\alpha_{1 \mathrm{D}}$ subtypes. Compound 1 exhibited enhanced antagonistic effect on $\alpha_{1 \mathrm{D}}$ subtype $\left(\mathrm{pA}_{2} 7.06\right)$ and excellent selectivity for $\alpha_{1 \mathrm{D}}$ over $\alpha_{1 \mathrm{~B}}\left(\alpha_{1 \mathrm{D}} / \alpha_{1 \mathrm{~B}}\right.$ ratio $\left.=79.4\right)$. To illustrate the relationship between antagonistic activity and chemical structure, molecular docking studies were performed using the homology models of $\alpha_{1}$ receptors. Binding mechanism indicated that small hydrophobic substituents attached to the arylpiperazine moiety were essential for rational design of $\alpha_{1 \mathrm{D}}$-selective antagonists.
\end{abstract}

Keywords: $\alpha_{1}$-Adrenoceptor antagonists, Arylpiperazine, X-ray crystallography, Molecular docking, Pharmacophore model 


\section{Introduction}

$\alpha_{1}$-adrenoceptors (ARs) belong to class A of the super family of $\mathrm{G}$ protein-coupled receptors (GPCRs) and play a key role in contracting vascular smooth and human prostate smooth muscles ${ }^{1}$. Based on their distinct pharmacological properties, $\alpha_{1}$-ARs are classified into three subtypes, namely $\alpha_{1 \mathrm{~A}}, \alpha_{1 \mathrm{~B}}$ and $\alpha_{1 \mathrm{D}} \cdot{ }^{2,3}$ In the last years, subtype-selective $\alpha_{1}$-AR antagonists were deemed to be attractive drug candidates for the treatment of benign prostatic hyperplasia (BPH) which is a common condition that severely impairs patient's health in aging males. ${ }^{4,5}$

Arylpiperazine derivatives exhibited extensive bioactivities including the management of BPH progression. ${ }^{6}$ Among this kind of compounds, arylpiperazine derivatives bearing a flavone nucleus (I) presented in Figure 1 showed similar antagonistic properties for $\alpha_{1}$-AR in comparison to the reference agent prazosin. ${ }^{7}$ Although quinazolinone-arylpiperazine derivative (II) displayed the $\alpha_{1}$-blocking activity less than non-selective antagonist prazosin, the compound fitted well with the ligand-based pharmacophore model for $\alpha_{1}$-AR antagonists which consisted of positive ionizable (PI), hydrophobic features (HY) and hydrogen bond acceptor (HBA) ${ }^{8}$ Pyrrolidin-2-one derivative of arylpiperazine (III) also exhibited high affinity for the $\alpha_{1}$ - $\mathrm{AR}\left(\mathrm{p} K_{\mathrm{i}}=7.30\right)$ and was further tested as $\alpha_{1 \mathrm{~A}}$-AR antagonist in vivo. ${ }^{9}$ Structure-activity relationship (SAR) studies of imidazo- and indol-arylpiperazine derivatives (IV) validated the pharmacophore model for $\alpha_{1}$-AR antagonists. ${ }^{10} 5$-arylidenehydantoin-arylpiperazine $(\mathbf{V})^{11}$, and pyridine-arylpiperazine $(\mathbf{V I})^{12}$ were also proved to possess good affinity for $\alpha_{1}$-AR in vitro. Particularly, arylpiperazine-derived naftopidil is subtype-selective antagonist with a 15 -fold selectivity for $\alpha_{1 \mathrm{D}}$ versus $\alpha_{1 \mathrm{~B}}$ receptor. ${ }^{13}$ On the other hand, carbazole derivatives displayed various biological activities, such as enzyme inhibition ${ }^{14,15}$, the anti-proliferation against different cancer cells lines ${ }^{16}$, and the $5-\mathrm{HT}_{7} \mathrm{R}$ blocking activity (VII). ${ }^{17}$

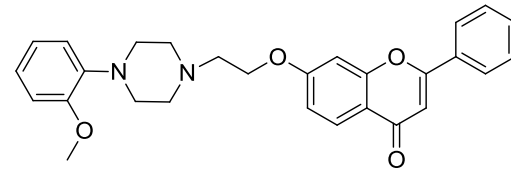

7-(2-(4-(2-methoxyphenyl) piperazin-1-yl)ethoxy)-2-phenyl-4H-chromen-4-one (I)

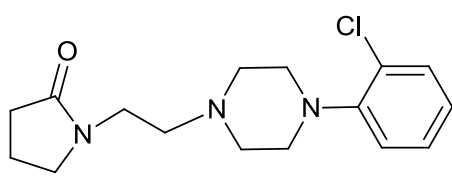

1-(2-(4-(2-chlorophenyl) piperazin-1-yl)ethyl)pyrrolidin-2-one (III)

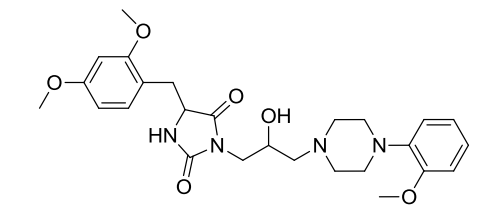

5-(2,4-dimethoxybenzyl)-3-(2-hydroxy-3-(4-(2-methoxypheny) piperazin-1-yl)propyl)imidazolidine-2,4-dione (V)

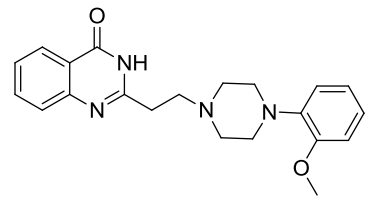

2-(2-(4-(2-methoxyphenyl) piperazin-1-yl)ethyl)quinazolin-4(3H)-one (II)

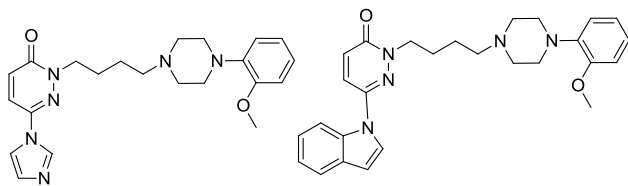

6-(1H-imidazol-1-yl)-2-(4-(4-(2-methoxyphenyl) 6-(1H-indol-1-yl)-2-(4-(4-(2-methoxyphenyl) piperazin-1-yl)butyl)pyridazin-3(2H)-one

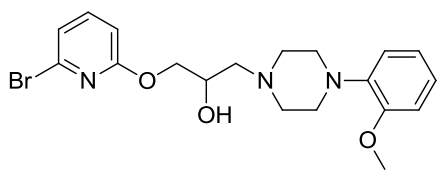

1-((6-bromopyridin-2-yl)oxy)-3-(4-(2-methoxyphenyl) piperazin-1-yl)propan-2-ol (VI) 

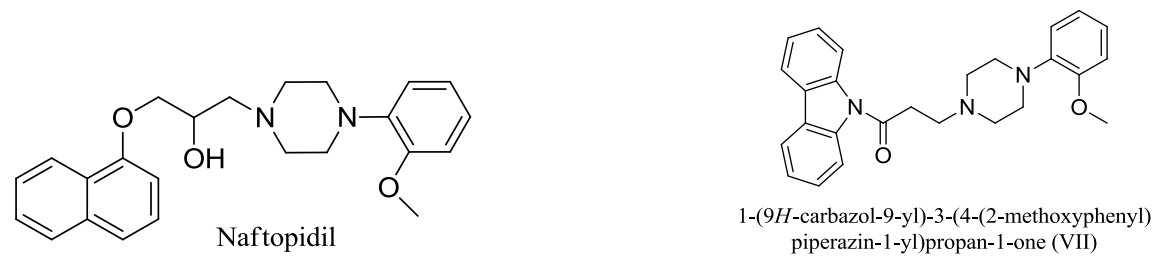

Figure 1. Chemical structures of arylpiperazine derivatives.

In this work, we designed novel $\alpha_{1}$-AR antagonists that had a three-carbon linker between arylpiperazine moiety and carbazole fragments (see Figure 2). The hypothesized pharmacophore model suggested that the hydrophobic regions are composed of carbazole group, the phenyl ring of the arylpiperazine moiety and the methoxyl substituent attached on the arylpiperazine, and the PI feature is the basic $\mathrm{N}$ atom on piperazine ring ${ }^{18}$, and the hydroxyl group is defined as hydrogen bond donor (HBD). Two carbazole-arylpiperazine derivatives were then synthesized, and fully characterized by NMR $\left({ }^{1} \mathrm{H}\right.$ and $\left.{ }^{13} \mathrm{C}\right)$, elemental analysis and single crystal $\mathrm{X}$-ray diffraction analysis. The antagonistic activities towards $\alpha_{1}$-AR were evaluated using functional assays in vitro. Molecular docking studies shed light on the relationship between antagonist structures and bioactivities against $\alpha_{1}$-AR subtypes. The work provides valuable clues for the design of subtype-selective $\alpha_{1}$-AR antagonists.

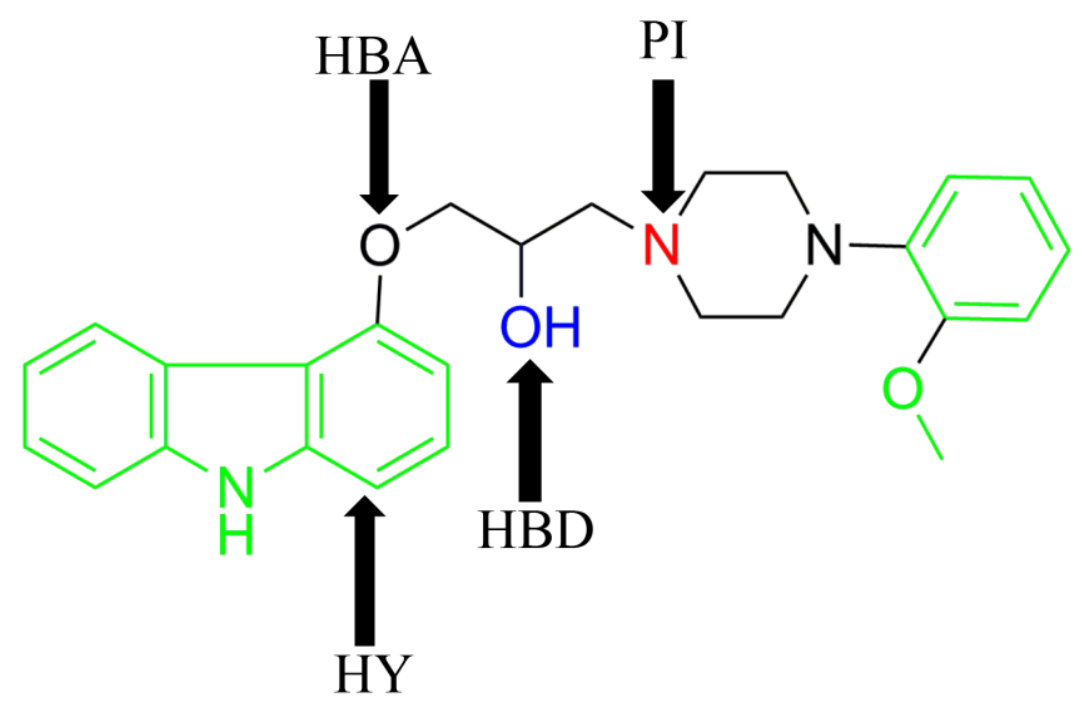

Figure 2. Visualization of pharmacophoric features for novel carbazole-arylpiperazine derivatives. Colour legend: green, hydrophobic features (HY); red, positive ionizable (PI); blue, hydrogen bond donor (HBD); black, hydrogen bond acceptor (HBA).

\section{Results and Discussion}

\subsection{Chemistry}

The title compounds $\mathbf{1}$ and $\mathbf{2}$ were synthesized in two steps starting from the commercially available carbazole-4-ol and 2-(chloromethyl)oxirane, as depicted in Scheme 1. The condensation of carbazole-4-ol and 2-(chloromethyl)oxirane gave the intermediate compound 
4-(oxiran-2-ylmethoxy)-9H-carbazole in the presence of TEBA. 1-phenylpiperazine derivatives were prepared according to a literature method. ${ }^{19}$ The final products ( $\mathbf{1}$ and $\left.\mathbf{2}\right)$ were afforded under reflux conditions, and further purified by silica gel column chromatography eluted by a mixture of ethyl acetate and petroleum ether $(1 / 5, \mathrm{v} / \mathrm{v})$. The structures of compounds $\mathbf{1}$ and $\mathbf{2}$ were characterized by their melting points, ${ }^{1} \mathrm{H}-\mathrm{NMR},{ }^{13} \mathrm{C}-\mathrm{NMR}$, element analysis and single-crystal diffraction.

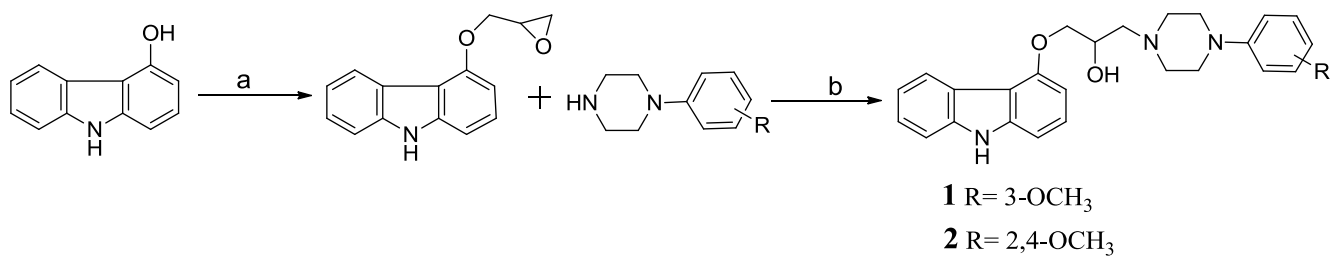

Reagents and conditions: (a) 2-(chloromethyl)oxirane, Benzyltriethylaminium.chloride (TEBA), $\mathrm{NaOH}, 70{ }^{\circ} \mathrm{C}$; (b) $\mathrm{CH}_{3} \mathrm{OH}$, reflux.

Scheme 1. Synthesis of the title compound $\mathbf{1}$ and $\mathbf{2}$.

\subsection{X-ray crystallography}

Compound 1 crystallizes in the monoclinic space group $C$ c. The asymmetric unit contains three crystallographically independent molecules. A representative crystal structure is presented in Figure 3. The crystal data and structural refinement of $\mathbf{1}$ are presented in Table 1. The low $R$ (5.32\% for $\mathbf{1}, 5.17 \%$ for 2 ) value in X-ray crystallography validated the synthesized structures.

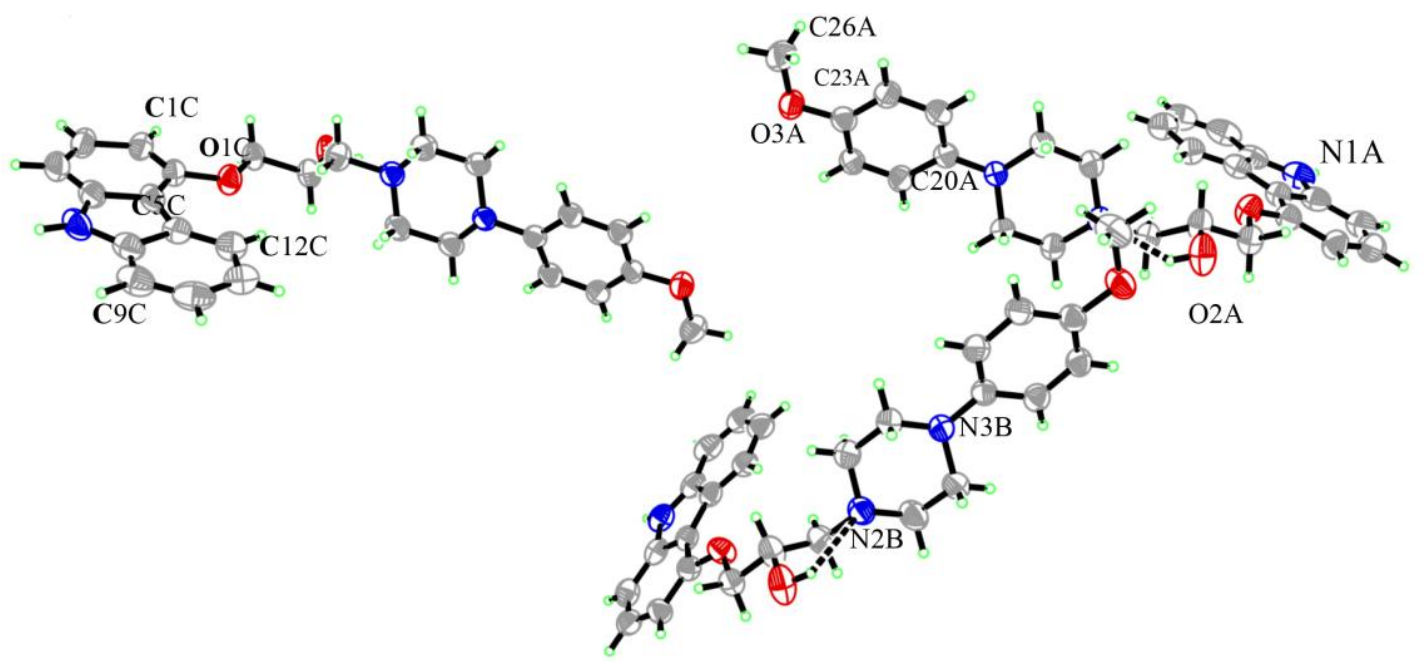

Figure 3. Crystallographic structure of $\mathbf{1}$ including three molecules in an asymmetric unit. Displacement ellipsoids are drawn at the $30 \%$ probability level, and intramolecular hydrogen bonds are presented in dashed lines.

Table 1 Crystal data and structural refinement of compounds $\mathbf{1}$ and $\mathbf{2}$.

\begin{tabular}{lll}
\hline Compound & $\mathbf{1}$ & \multicolumn{1}{c}{$\mathbf{2}$} \\
\hline Chemical formula & $3\left(\mathrm{C}_{26} \mathrm{H}_{29} \mathrm{~N}_{3} \mathrm{O}_{3}\right)$ & $\mathrm{C}_{27} \mathrm{H}_{31} \mathrm{~N}_{3} \mathrm{O}_{4}$ \\
$M_{\mathrm{r}}$ & 1294.56 & 461.55
\end{tabular}




\begin{tabular}{|c|c|c|}
\hline Temperature (K) & $293(2)$ & $293(2)$ \\
\hline Crystal system, space group & Monoclinic, $C \mathrm{c}$ & Monoclinic, $P 2{ }_{1} / \mathrm{c}$ \\
\hline$a, b, c(\AA)$ & $\begin{array}{l}\text { 17.519(4), 33.882(7), } \\
12.440(3)\end{array}$ & $8.4876(17), 11.168(2), 26.600(5)$ \\
\hline$\alpha, \beta, \gamma\left(^{\circ}\right)$ & 90, 104.47(3), 90 & 90, 97.26(3), 90 \\
\hline$V\left(\AA^{3}\right)$ & $7150(3)$ & 2501.2(9) \\
\hline $\mathrm{Z}$ & 4 & 4 \\
\hline$\rho_{\text {calc }}\left(\mathrm{g} / \mathrm{cm}^{3}\right)$ & 1.203 & 1.226 \\
\hline$\mu\left(\mathrm{mm}^{-1}\right)$ & 0.636 & 0.669 \\
\hline $\mathrm{F}(000)$ & 2760 & 984 \\
\hline Crystal size $\left(\mathrm{mm}^{3}\right)$ & $0.1 \times 0.1 \times 0.1$ & $0.3 \times 0.2 \times 0.2$ \\
\hline Radiation & $\mathrm{Cu} \mathrm{K \alpha}(\lambda=1.54178)$ & $\mathrm{Cu} \mathrm{K} \alpha(\lambda=1.54178)$ \\
\hline$\theta$ range $\left(^{\circ}\right)$ & 4.15 to 68.12 & 3.35 to 68.21 \\
\hline$T_{\min } / T_{\max }$ & $0.938 / 0.938$ & $0.852 / 0.875$ \\
\hline Reflections collected/unique/observed & $41602 / 12258 / 7537$ & $27567 / 4510, / 3395$ \\
\hline$R_{\text {int }}$ & 0.0329 & 0.0364 \\
\hline Goodness-of-fit on $F^{2}$ & 1.071 & 1.093 \\
\hline $\mathrm{R}_{1} / \mathrm{wR}_{2}[\mathrm{I}>=2 \sigma(\mathrm{I})]$ & $0.0532 / 0.1504$ & $0.0517 / 0.1499$ \\
\hline $\mathrm{R}_{1} / \mathrm{wR}_{2}$ [all data] & $0.0893 / 0.2056$ & $0.0644 / 0.1640$ \\
\hline$\Delta \rho_{\max } / \Delta \rho_{\min }\left(\mathrm{e} \AA^{-3}\right)$ & $0.30 /-0.14$ & $0.31 /-0.18$ \\
\hline
\end{tabular}

As depicted in Table 2, most bond lengths are within the normal ranges, e.g., the $\mathrm{C}-\mathrm{C}$ single bond in the range of 1.498(8)-1.516(8) $\AA$, and the $\mathrm{O}-\mathrm{C}$ bond lengths from 1.382(7) to 1.419(7) $\AA$ (see Table 2). The torsion angle for $\mathrm{O}(1)-\mathrm{C}(13)-\mathrm{C}(14)-\mathrm{C}(15)$ is $62.1(7)^{\circ},-59.3(7)^{\circ}$ and $-61.9(7)^{\circ}$ for the three independent molecules (A, B and C), respectively, which indicates that conformation A distinctly differs from another two conformers. The carbazole ring of molecular B is almost perpendicular to $[C(20), C(21), C(22), C(23), C(24), C(25)]$ aromatic plane with a dihedral angle of $81.44(14)^{\circ}$, and the corresponding dihedral angles of molecular $\mathrm{A}$ and $\mathrm{C}$ are $74.23(16)^{\circ}$ and $77.93(16)^{\circ}$, respectively.

Table 2 Selected geometric parameters of compound $\mathbf{1}\left(\AA^{\circ},{ }^{\circ}\right)$.

\begin{tabular}{llllll}
\hline Bonds & Dist. & Bonds & Dist. & Bonds & Dist. \\
\hline $\mathrm{O}(1 \mathrm{~A})-\mathrm{C}(6 \mathrm{~A})$ & $1.386(7)$ & $\mathrm{O}(1 \mathrm{~B})-\mathrm{C}(6 \mathrm{~B})$ & $1.377(7)$ & $\mathrm{O}(1 \mathrm{C})-\mathrm{C}(6 \mathrm{C})$ & $1.382(7)$ \\
$\mathrm{O}(2 \mathrm{~A})-\mathrm{C}(14 \mathrm{~A})$ & $1.419(7)$ & $\mathrm{O}(1 \mathrm{~B})-\mathrm{C}(6 \mathrm{~B})$ & $1.377(7)$ & $\mathrm{O}(1 \mathrm{C})-\mathrm{C}(6 \mathrm{C})$ & $1.382(7)$ \\
$\mathrm{O}(3 \mathrm{~A})-\mathrm{C}(23 \mathrm{~A})$ & $1.381(7)$ & $\mathrm{O}(3 \mathrm{~B})-\mathrm{C}(23 \mathrm{~B})$ & $1.381(6)$ & $\mathrm{O}(3 \mathrm{C})-\mathrm{C}(23 \mathrm{C})$ & $1.391(6)$ \\
$\mathrm{N}(1 \mathrm{~A})-\mathrm{C}(4 \mathrm{~A})$ & $1.374(9)$ & $\mathrm{N}(1 \mathrm{~B})-\mathrm{C}(4 \mathrm{~B})$ & $1.384(8)$ & $\mathrm{N}(1 \mathrm{C})-\mathrm{C}(4 \mathrm{C})$ & $1.383(8)$ \\
$\mathrm{N}(2 \mathrm{~A})-\mathrm{C}(19 \mathrm{~A})$ & $1.444(8)$ & $\mathrm{N}(2 \mathrm{~B})-\mathrm{C}(19 \mathrm{~B})$ & $1.458(8)$ & $\mathrm{N}(2 \mathrm{C})-\mathrm{C}(19 \mathrm{C})$ & $1.448(7)$ \\
$\mathrm{C}(1 \mathrm{~A})-\mathrm{C}(2 \mathrm{~A})$ & $1.410(9)$ & $\mathrm{C}(1 \mathrm{~B})-\mathrm{C}(2 \mathrm{~B})$ & $1.403(8)$ & $\mathrm{C}(1 \mathrm{C})-\mathrm{C}(2 \mathrm{C})$ & $1.402(9)$ \\
$\mathrm{C}(7 \mathrm{~A})-\mathrm{C}(8 \mathrm{~A})$ & $1.381(9)$ & $\mathrm{C}(7 \mathrm{~B})-\mathrm{C}(8 \mathrm{~B})$ & $1.390(8)$ & $\mathrm{C}(7 \mathrm{C})-\mathrm{C}(8 \mathrm{C})$ & $1.390(8)$ \\
$\mathrm{C}(13 \mathrm{~A})-\mathrm{C} 14(\mathrm{~A})$ & $1.498(8)$ & $\mathrm{C}(13 \mathrm{~B})-\mathrm{C} 14(\mathrm{~B})$ & $1.509(8)$ & $\mathrm{C}(13 \mathrm{C})-\mathrm{C}(14 \mathrm{C})$ & $1.516(8)$ \\
$\mathrm{Angle}$ & $\left({ }^{\circ}\right)$ & $\mathrm{Angle}$ & $\left({ }^{\circ}\right)$ & $\mathrm{Angle}$ & $\left({ }^{\circ}\right)$ \\
$\mathrm{O}(1 \mathrm{~A})-\mathrm{C}(13 \mathrm{~A})-\mathrm{C}(14 \mathrm{~A})$ & $106.3(5)$ & $\mathrm{O}(1 \mathrm{~B})-\mathrm{C}(13 \mathrm{~B})-\mathrm{C}(14 \mathrm{~B})$ & $106.1(4)$ & $\mathrm{O}(1 \mathrm{C})-\mathrm{C}(13 \mathrm{C})-\mathrm{C}(14 \mathrm{C})$ & $105.3(5)$ \\
$\mathrm{N}(1 \mathrm{~A})-\mathrm{C}(4 \mathrm{~A})-\mathrm{C}(5 \mathrm{~A})$ & $108.5(7)$ & $\mathrm{N}(1 \mathrm{~B})-\mathrm{C}(4 \mathrm{~B})-\mathrm{C}(5 \mathrm{~B})$ & $107.5(6)$ & $\mathrm{N}(1 \mathrm{C})-\mathrm{C}(4 \mathrm{C})-\mathrm{C}(5 \mathrm{C})$ & $107.2(6)$ \\
$\mathrm{C}(13 \mathrm{~A})-\mathrm{C}(14 \mathrm{~A})-\mathrm{C}(15 \mathrm{~A})$ & $113.5(6)$ & $\mathrm{C}(13 \mathrm{~B})-\mathrm{C}(14 \mathrm{~B})-\mathrm{C}(15 \mathrm{~B})$ & $115.9(5)$ & $\mathrm{C}(13 \mathrm{C})-\mathrm{C}(14 \mathrm{C})-\mathrm{C}(15 \mathrm{C})$ & $113.1(5)$
\end{tabular}




\begin{tabular}{|c|c|c|c|c|c|}
\hline$O(1 A)-C(13 A)-C(14 A)-C(15 A)$ & $62.1(7)$ & $\mathrm{O}(1 \mathrm{~B})-\mathrm{C}(13 \mathrm{~B})-\mathrm{C}(14 \mathrm{~B})-\mathrm{C}(15 \mathrm{~B})$ & $-59.3(7)$ & $\mathrm{O}(1 \mathrm{C})-\mathrm{C}(13 \mathrm{C})-\mathrm{C}(14 \mathrm{C})-\mathrm{C}(15 \mathrm{C})$ & $-62.9(7)$ \\
\hline $\mathrm{N}(2 \mathrm{~A})-\mathrm{C}(16 \mathrm{~A})-\mathrm{C}(17 \mathrm{~A})-\mathrm{N}(3 \mathrm{~A})$ & $58.5(7)$ & $\mathrm{N}(2 \mathrm{~B})-\mathrm{C}(16 \mathrm{~B})-\mathrm{C}(17 \mathrm{~B})-\mathrm{N}(3 \mathrm{~B})$ & $57.2(8)$ & $\mathrm{N}(2 \mathrm{C})-\mathrm{C}(16 \mathrm{C})-\mathrm{C}(17 \mathrm{C})-\mathrm{N}(3 \mathrm{C})$ & $56.9(8)$ \\
\hline
\end{tabular}

The intra- and intermolecular interactions are of considerable interest in investigating the packing structures. Intramolecular $\mathrm{O}(2)-\mathrm{H} \cdots \mathrm{N}(2) \mathrm{H}$-bond results in the formation of the pseudo-five-membered rings. Intermolecular hydrogen bonds play an important role in stabilizing the packing structure (Figure S1 and Table 3). In addition, $\mathrm{C}-\mathrm{H} \cdots \pi$ interactions reinforce the three-dimensional structure with a centroid distance of $3.472(0) \AA[\mathrm{H} \cdots \mathrm{Cg}=2.58 \AA$; $\angle$ $\mathrm{C}(10 \mathrm{~B})-\mathrm{H}(10 \mathrm{~B}) \cdots \mathrm{Cg}=160^{\circ} ; \mathrm{Cg}$ is the centroid of benzene ring; Symmetry code: $-1 / 2+x, 1 / 2-y$, $-1 / 2+z]$.

$\underline{\text { Table } 3 \text { Intermolecular hydrogen bonds for compound } \mathbf{1}\left(\AA,{ }^{\circ}\right) .}$

\begin{tabular}{lrlll}
\hline $\mathrm{D}-\mathrm{H} \cdots \mathrm{A}$ & $\mathrm{D}-\mathrm{H}$ & $\mathrm{H} \cdots \mathrm{A}$ & $\mathrm{D} \cdots \mathrm{A}$ & $\mathrm{D}-\mathrm{H} \cdots \mathrm{A}\left({ }^{\circ}\right)$ \\
\hline $\mathrm{N}(1 \mathrm{~B})-\mathrm{H}(1 \mathrm{~B}) \cdots \mathrm{O}(2 \mathrm{~A})^{\mathrm{i}}$ & 0.86 & 2.05 & $2.887(7)$ & 165 \\
$\mathrm{O}(2 \mathrm{~A})-\mathrm{H}(2 \mathrm{~A}) \cdots \mathrm{O}(3 \mathrm{~B})$ & 0.82 & 2.03 & $2.736(4)$ & 144 \\
$\mathrm{O}(2 \mathrm{~B})-\mathrm{H}(2 \mathrm{~B}) \cdots \mathrm{O}(3 \mathrm{~A})^{\mathrm{ii}}$ & 0.82 & 2.15 & $2.825(6)$ & 140 \\
$\mathrm{O}(2 \mathrm{C})-\mathrm{H}(2 \mathrm{C}) \cdots \mathrm{O}(3 \mathrm{C})^{\mathrm{iii}}$ & 0.82 & 2.09 & $2.775(6)$ & 141 \\
$\mathrm{~N}(1 \mathrm{~A})-\mathrm{H}(1 \mathrm{AA}) \cdots \mathrm{O}(2 \mathrm{~B})^{\mathrm{IV}}$ & 0.86 & 2.01 & $2.840(8)$ & 161 \\
\hline
\end{tabular}

Symmetry code: (i) $-1 / 2+x, 1 / 2+y, z$ (ii) $x, y, 1+z$ (iii) $x,-y,-1 / 2+z$ (IV)

$-1 / 2+\mathrm{x},-1 / 2+\mathrm{y},-1+\mathrm{z}$

The crystal of 2 also belongs to monoclinic system with space group $P 2_{1} / \mathrm{c}$, and crystal data are presented in Table 1. Ortho- and meta-methoxy stay almost coplanar with the benzene, since torsion angles of $\mathrm{C}(21)-\mathrm{C}(22)-\mathrm{O}(4)-\mathrm{C}(27)$ and $\mathrm{C}(20)-\mathrm{C}(25)-\mathrm{O}(3)-\mathrm{C}(26)$ are $-174.5(2)^{\circ}$ and $161.4(2)^{\circ}$, respectively. The dihedral angle between carbazole and benzene ring is $44.0(6)^{\circ}$, which is much smaller as compared to $\mathbf{1}$. The conformational discrepancy of two X-ray structures is likely ascribed to the formation of additional intramolecular $\mathrm{C}(18)-\mathrm{H} \cdots \mathrm{O}(3) \mathrm{H}$-bond in 2, see Figure 4.

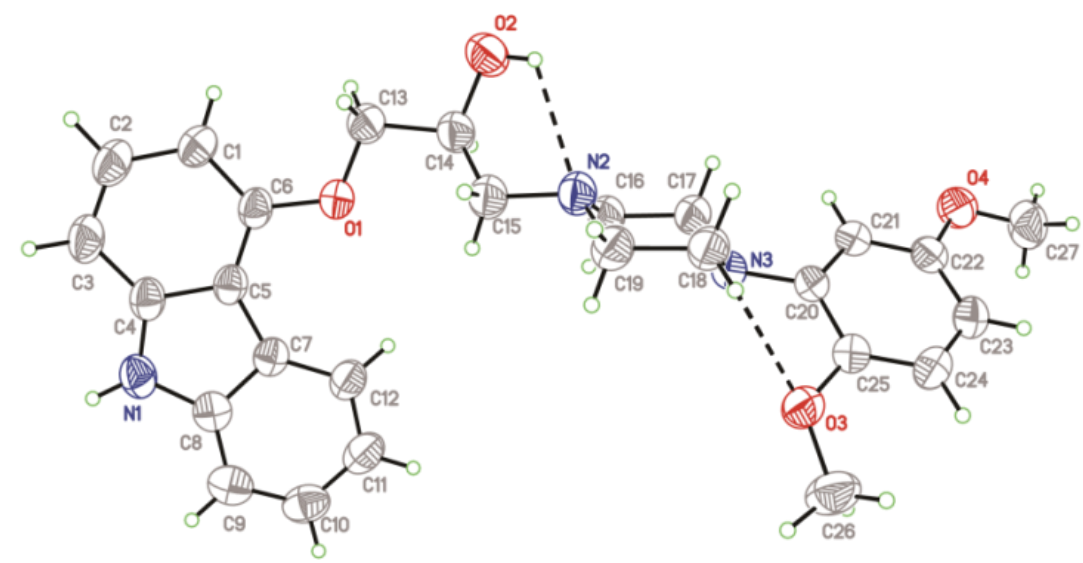

Figure 4. Crystallographic structure of 2 in an asymmetric unit. Displacement ellipsoids are at the $30 \%$ probability level, and intramolecular hydrogen bonds $\mathrm{O}(2)-\mathrm{H} \cdots \mathrm{N}(2)$ and $\mathrm{C}(18)-\mathrm{H} \cdots \mathrm{O}(3)$ are presented in dashed lines. 
Intramolecular hydrogen bonds $[\mathrm{O}(2)-\mathrm{H} \cdots \mathrm{N}(2)$ and $\mathrm{C}(18)-\mathrm{H} \cdots \mathrm{O}(3)]$ generate non-planar five-membered and six-membered pseudo rings, respectively. As for the molecular packing (Figure S2), two molecules form a $R_{1}^{2}(5)$ motif via intermolecular hydrogen bonds $\mathrm{N}(1)-\mathrm{H} \cdots \mathrm{O}(3)$ and $\mathrm{N}(1)-\mathrm{H} \cdots \mathrm{N}(3)$. Thus, the solid-state conformation and packing structure of $\mathbf{2}$ are directly related to hydrogen bonds.

\subsection{D Pharmacophore model investigations}

Pharmacophore model is a benefit to designing the effective and safety antagonists at $\alpha_{1}$-AR subtypes. Figure 5 listed the key pharmacophoric features of subtype-selective antagonists on the basis of the reported structures. ${ }^{8,20}$ It can be seen that X-ray crystallographic structures of $\mathbf{1}$ and $\mathbf{2}$ were obviously distinguished from the reported pharmacophoric model for $\alpha_{1 \mathrm{~A}}-\mathrm{AR}$ antagonists, despite the distance between PI and HY1 was nearly equal. In comparison to $\alpha_{1 \mathrm{~B}}-\mathrm{AR}$ antagonists model, crystal structures of $\mathbf{1}$ and $\mathbf{2}$ did not match the three pharmacophoric features. This case was also confirmed by biological activities against $\alpha_{1}$-AR that the two agents had low potency at the $\alpha_{1 \mathrm{~B}}$ receptor (see Table 4). Interestingly, their crystal data were satisfied with the model for selective $\alpha_{1 \mathrm{D}}$-AR antagonists. Antagonistic effects on $\alpha_{1}$-AR indicated that 1 displayed the highest affinity to $\alpha_{1 \mathrm{D}}$ in comparison with $\alpha_{1 \mathrm{~A}}$ and $\alpha_{1 \mathrm{~B}}$, whereas 2 exhibited discrepancy results that the potency against $\alpha_{1 \mathrm{~B}}$ receptor is over than that of $\alpha_{1 \mathrm{D}}$.
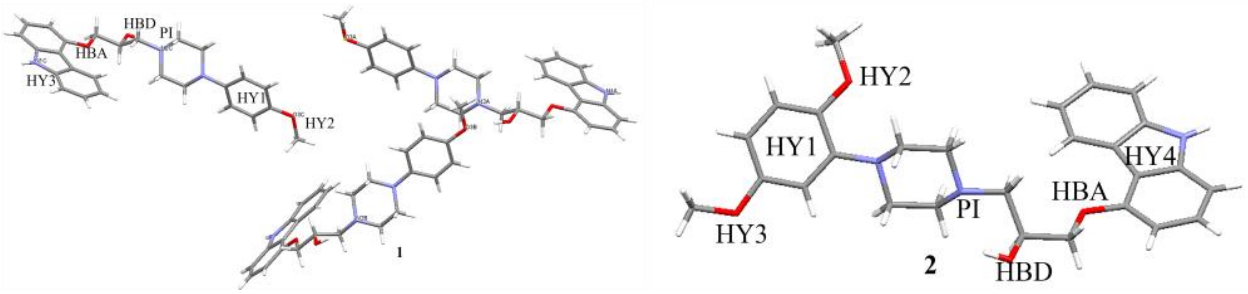

\begin{tabular}{lllll}
\hline & $\begin{array}{l}\text { Distance }(\AA) \\
(\mathrm{PI}-\mathrm{HY} 1)\end{array}$ & $\begin{array}{l}\text { Distance }(\AA) \\
(\mathrm{PI}-\mathrm{HBA})\end{array}$ & $\begin{array}{l}\text { Distance }(\AA) \\
(\mathrm{PI}-\mathrm{HY} 3)\end{array}$ & $\begin{array}{l}\text { Distance }(\AA) \\
(\mathrm{PI}-\mathrm{HBD})\end{array}$ \\
\hline$\alpha_{1 \mathrm{~A}}$-AR antagonists & 5.5 & 7.1 & -- & -- \\
$\alpha_{1 \mathrm{~B}}$-AR antagonists & 6.2 & -- & 7.8 & 4.9 \\
$\alpha_{1 \mathrm{D}}$-AR antagonists & 5.4 & 4.5 & -- & - \\
X-ray structure of $\mathbf{1}$ & $5.64(\mathrm{~A})$ & $4.17(\mathrm{~A})$ & $6.52(\mathrm{~A})$ & $2.92(\mathrm{~A})$ \\
& $5.65(\mathrm{~B})$ & $4.22(\mathrm{~B})$ & $6.55(\mathrm{~B})$ & $2.88(\mathrm{~B})$ \\
& $5.64(\mathrm{C})$ & $4.20(\mathrm{C})$ & $6.55(\mathrm{C})$ & $2.93(\mathrm{C})$ \\
X-ray structure of $\mathbf{2}$ & 5.66 & 4.21 & 7.23 & 2.78 \\
\hline
\end{tabular}

Figure 5. Visualization of pharmacophoric features of $\mathbf{1}$ and $\mathbf{2}$ based on Barbaro's model (upper) and comparison of important distances between pharmacophoric features in reported subtype-selective $\alpha_{1}$-AR antagonists and crystallographic structures of $\mathbf{1}$ and $\mathbf{2}$ (below).

\subsection{Biological evaluation in vitro}

To evaluate the subtype selectivity, the antagonistic effects of compounds $\mathbf{1}$ and $\mathbf{2}$ were characterized (Table 4). Compound 2, which possesses two methoxyl groups at position 2 and 5, showed strong antagonistic activity on $\alpha_{1 \mathrm{~B}}$ subtype $\left(\mathrm{pA}_{2} 7.13\right)$, but had poor $\alpha_{1 \mathrm{~A}}, \alpha_{1 \mathrm{D}}$ subtype selectivity over $\alpha_{1 \mathrm{~B}}\left(\alpha_{1 \mathrm{~A}} / \alpha_{1 \mathrm{~B}}\right.$ ratio $=0.2, \alpha_{1 \mathrm{D}} / \alpha_{1 \mathrm{~B}}$ ratio $\left.=0.5\right)$. As compared to 2 , the 4-methoxyl-substituted derivative 1 exhibited enhanced antagonistic effect on $\alpha_{1 \mathrm{D}}$ subtype ( $\mathrm{pA}_{2}$ 
7.06) and excellent selectivity concerning both $\alpha_{1 \mathrm{D}}$ subtype and $\alpha_{1 \mathrm{~A}}$ subtype over $\alpha_{1 \mathrm{~B}}\left(\alpha_{1 \mathrm{D}} / \alpha_{1 \mathrm{~B}}\right.$ ratio $=79.4, \alpha_{1 \mathrm{~A}} / \alpha_{1 \mathrm{~B}}$ ratio $\left.=3.7\right)$. Moreover, the selectivity activity of 1 towards $\alpha_{1 \mathrm{D}}$ subtype over $\alpha_{1 \mathrm{~B}}$ was $\sim 5$-fold higher than that of naftopidil (NAF) which was served as the positive control $^{21}$, despite 1 had decreased potency on $\alpha_{1 \mathrm{D}}$ subtype ( $\left.\mathrm{pA}_{2} 7.06\right)$ when compared to NAF. The results of isolated tissue analysis in vitro revealed that the para-substituent present on the arylpiperazine moiety (1) led to the excellent selectivity against the $\alpha_{1 \mathrm{D}}$ receptor, and two methoxyl substituents located at the position ortho and meta (2) improved potency on $\alpha_{1 \mathrm{~B}}$.

Table 4 Functional antagonistic potency of compounds 1 and 2 (expressed as $\mathrm{pA}_{2}$ ) on $\alpha_{1}$-adrenoceptor subtypes of SD rat isolated tissues: vas deferens $\left(\alpha_{1 \mathrm{~A}}\right)$, spleen $\left(\alpha_{1 \mathrm{~B}}\right)$ and thoracic aorta $\left(\alpha_{1 \mathrm{D}}\right)$

\begin{tabular}{|c|c|c|c|c|c|c|}
\hline \multirow[t]{2}{*}{ Comp. } & \multicolumn{3}{|c|}{$\begin{array}{l}p \mathrm{~A}_{2}{ }^{\mathrm{a}} \\
\text { (slope) }\end{array}$} & \multicolumn{3}{|c|}{ Selectivity ratio ${ }^{b}$} \\
\hline & $\alpha_{1 \mathrm{~A}}$ & $\alpha_{1 \mathrm{~B}}$ & $\alpha_{1 \mathrm{D}}$ & $\alpha_{1 \mathrm{D}} / \alpha_{1 \mathrm{~A}}$ & $\alpha_{1 \mathrm{D}} / \alpha_{1 \mathrm{~B}}$ & $\alpha_{1 \mathrm{~A}} / \alpha_{1 \mathrm{~B}}$ \\
\hline \multirow[t]{2}{*}{1} & $5.73 \pm 0.07$ & $5.16 \pm 0.11$ & $7.06 \pm 0.14$ & 21.4 & 79.4 & 3.7 \\
\hline & $(1.01)$ & $(1.20)$ & (1.15) & & & \\
\hline \multirow[t]{2}{*}{2} & $6.36 \pm 0.10$ & $7.13 \pm 0.21$ & $6.85 \pm 0.10$ & 3.1 & 0.5 & 0.2 \\
\hline & (1.45) & $(0.91)$ & (1.34) & & & \\
\hline Naftopidil $^{\mathbf{c}}$ & $7.48 \pm 0.07$ & $6.75 \pm 0.11$ & $7.93 \pm 0.11$ & 2.82 & 15.14 & 5.37 \\
\hline
\end{tabular}

${ }^{\mathrm{a}} \mathrm{pA}_{2}$ values \pm SEM $(\mathrm{n}=5-8)$ were calculated from Schild plots, $\mathrm{pA}_{2}$ is the positive value of the line intercept derived through plotting $\log (\mathrm{Dr}-1)$ vs. $\log$ [antagonist].

${ }^{\mathrm{b}}$ Antilog of $\triangle \mathrm{pA}_{2}$.

${ }^{\mathrm{c}}$ obtained in ref. 20

\subsection{Binding modes of ligand- $\alpha_{1}$ complexes}

$\alpha_{1}$-AR is a member of the G protein-coupled receptors (GPCRs) family that are constructed by seven transmembrane (TM) helices, $\mathrm{N}$ - and C-terminal fragments, and intra- and extracellular loop (ECL) regions. ${ }^{22}$ The accurate 3D structures of $\alpha_{1}$-AR with high resolutions had not been obtained, homology-modeling strategies thus provided a viable tool for structure-based $\alpha_{1}$-AR antagonist design.

Molecular docking studies shed light on the binding mechanism of ligand- $\alpha_{1}$-subtype complex which can explain the observed antagonistic activities of $\mathbf{1}$ and $\mathbf{2}$. As shown in Figure 6A, compound 1 was localized in the hydrophobic pocket involving TM I, II and VII. The OH group formed a hydrogen bond $(2.4 \AA)$ with the carbonyl oxygen atom of Gln177 in the ECL2 region that has been proved to be essential for GPCR activation. ${ }^{23}$ The carbazole and benzene rings were mainly engaged in hydrophobic interactions with Phe308, Phe312 and Trp316 residues. In the 2- $\alpha_{1 \mathrm{~A}}$-adrenoceptor complex, the hydroxyl group formed a H-bond with $\operatorname{Gln} 177$ (2.3 $\AA$ between the oxygen atom of hydroxyl group and the amide oxygen atom of Gln177). The major difference in the best poses of $\mathbf{1}$ and $\mathbf{2}$ was the localization of arylpiperazine moiety on the outer surface of TM helices.

It can be seen from Figure 6B that the carbazole rings of $\mathbf{1}$ and $\mathbf{2}$ entered into the hydrophobic region defined by Phe310, Phe311 and Phe330 residues of TM VI, and the benzene moiety contacted via hydrophobic interactions with residues Trp121, Phe334 and Tyr338 of TM VII. The OH group of $\mathbf{1}$ formed a hydrogen bond (2.9 $\AA$ ) with residue Ala122 of TM III; while compound 2 
established a H-bond (1.9 ̊) with Val197 of ECL2, which improved the antagonistic activity against $\alpha_{1 \mathrm{~B}}$ subtype.

Docking results showed that $\mathbf{1}$ was located in a hydrophobic pocket composed of TM III, V and VII in $\alpha_{1 \mathrm{D}}$ subtype (Figure 6C). The carbazole plane was engaged in hydrophobic interactions with residues Trp112 of TM II, Phe328 and Tyr332 of TM VII, and the aromatic ring was also involved in hydrophobic interaction with the region formed by Phe304 and Phe305 of TM VI. The protonated piperazine moiety formed a weak electrostatic interaction with Glu190 of ECL2 (4.1 A between the nitrogen atom of piperazine ring and carboxylic acid group of Glu190). For the title compound 2, the $\mathrm{OH}$ group formed an H-bond to Cys186 (2.8 $\mathrm{A})$.

The binding modes were similar in antagonists 1 and 2 binding to $\alpha_{1 \mathrm{~A}}$ receptor except that their terminal aromatic moieties presented differential localizations. The carbazole group may play an important role in the binding affinity for the $\alpha_{1 \mathrm{~A}}$ receptor as it extended into the hydrophobic pocket. As revealed by the docking simulations, the binding poses differences between $\mathbf{1}$ and $\mathbf{2}$ was suggested to be associated with the decreased potency of $\mathbf{1}\left(\mathrm{pA}_{2} 5.16\right)$ and comparatively high potency of $2\left(\mathrm{pA}_{2} 7.13\right)$ on the $\alpha_{1 \mathrm{~B}}$ receptor. Recognition of Val197 of ECL2 improved the binding affinity of antagonist 2 for $\alpha_{1 \mathrm{~B}}$-AR. The above results discovered that favorable antagonistic activity against $\alpha_{1 \mathrm{~B}}$ receptor could be ascribed to high hydrophobicity of the aromatic moiety and binding affinity to key residues of ECL2. Interestingly, docking modes (Fig. 6C) demonstrated that the arylpiperazine moieties of $\mathbf{1}$ and $\mathbf{2}$ as "head" directed toward helices III, V and VII, and the carbazole group as "tail" stayed the region near the entrance of the binding pocket of $\alpha_{1 \mathrm{D}}$, which is contrary to the binding modes of the two antagonists to $\alpha_{1 \mathrm{~A}}$ and $\alpha_{1 \mathrm{~B}}-\mathrm{AR}$.

A)

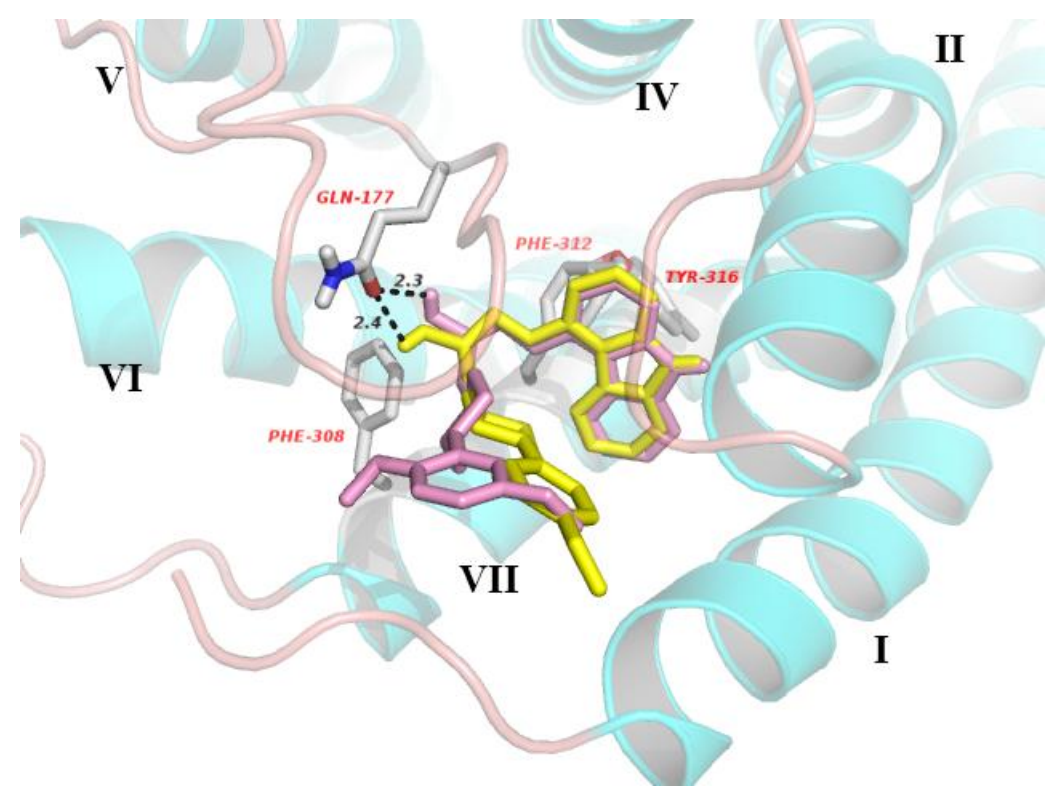


B)

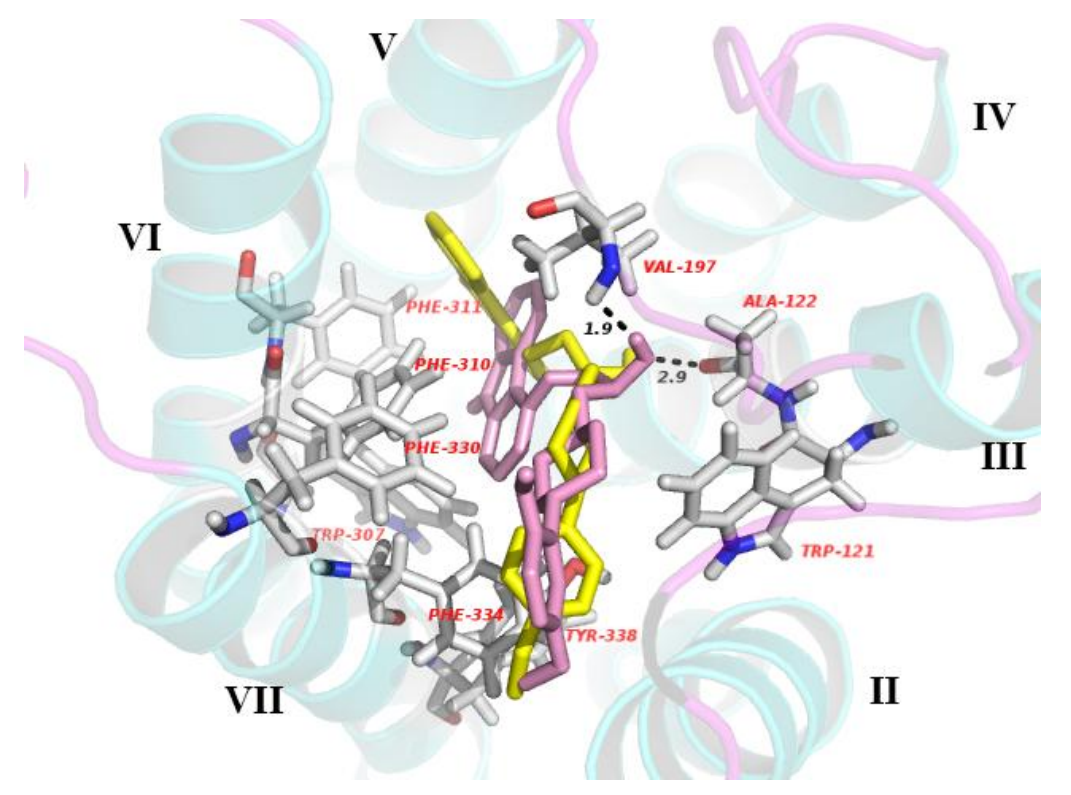

C)

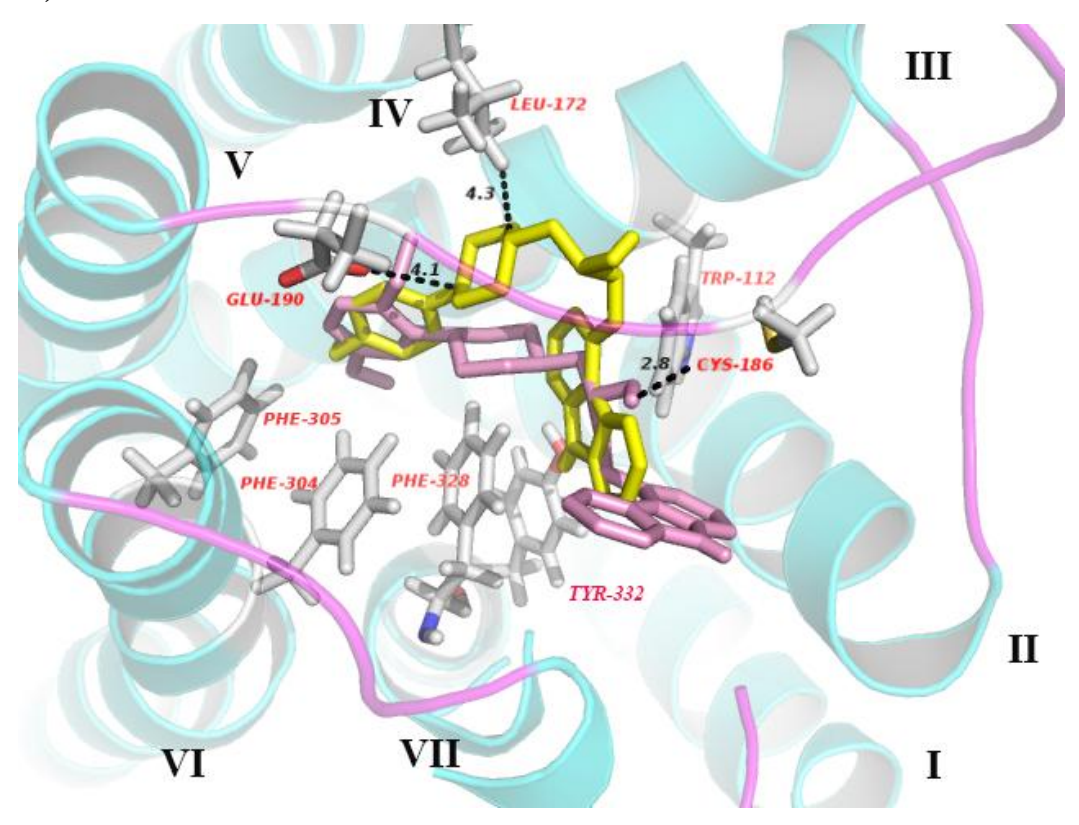

Figure 6. Selected docking poses of the $\alpha_{1}$-AR agonists $\mathbf{1}$ (depicted in yellow) and $\mathbf{2}$ (depicted in pink) into the putative binding sites of $\alpha_{1 \mathrm{~A}}(\mathrm{~A}), \alpha_{1 \mathrm{~B}}(\mathrm{~B})$ and $\alpha_{1 \mathrm{D}}$ (C) subtypes. The two antagonists are shown in stick representation. The receptors are shown in cartoon representation with cyan alpha helices, green beta sheets and magenta loops. The seven TM helices are labeled by I, II, III, IV, V, VI and VII, respectively. Dashed lines represent the hydrogen bonds or electrostatic interactions.

\section{Conclusions}

$\mathrm{BPH}$ is a progressive condition that severely impairs the quality of life of the aged male 
patients. $\alpha_{1}$-adrenoceptor antagonists were seemed to be the most effective therapeutic strategy for BPH. In this work, two novel 1-((9H-carbazol-4-yl)oxy)-3-(4-phenylpiperazin-1-yl)propan-2-ol derivatives were synthesized and characterized by NMR and X-ray crystallographic studies. Both crystals of the title compounds $\mathbf{1}$ and $\mathbf{2}$ are monoclinic with space group $C \mathrm{c}$ and $P 2_{1} / \mathrm{c}$, respectively. Intra- and inter-molecular hydrogen bonds play a significant role in sustaining the specific conformation and three-dimensional structures. To elucidate the relationship between structural properties and antagonistic activity, molecular docking studies using a homology model of $\alpha_{1}$-AR was carried out. The results obtained from docking simulations showed that: i) the terminal carbazole group entered into the hydrophobic regions surrounded by transmembrane helices, which contributed to the improved potency against $\alpha_{1 \mathrm{~A}}$ and $\alpha_{1 \mathrm{~B}}$ subtypes; ii) high hydrophobicity of aromatic moiety was benefit to the binding affinity for both $\alpha_{1 \mathrm{~A}}$ and $\alpha_{1 \mathrm{~B}} \mathrm{AR}$, but had the opposite effect on $\alpha_{1 \mathrm{D}}$ subtype, and the $\mathrm{OH}$ group improved the potency of $\alpha_{1 \mathrm{~B}}$ subtype through recognizing the key residues of ECL2 and iii) introducing small hydrophobic groups to the arylpiperazine moiety was essential for rational design of $\alpha_{1 D^{-}}$selective antagonists.

\section{Experimental}

\subsection{Chemistry}

All reagents and solvents were of analytical grade and commercially available. Melting points were determined on a SGW X-4 micro melting point apparatus (Shanghai Precision \& Scientific Instrument Co., Ltd, Shanghai, China). NMR spectra were accomplished on a Bruker AVANCE-500 spectrometer in DMSO using TMS as the internal standard, and coupling constants $(J)$ were quoted in Hz. Single-crystal X-ray diffraction data of compounds $\mathbf{1}$ and $\mathbf{2}$ were collected on a Rigaku RAPID II diffractometer with $\mathrm{Cu} \mathrm{K} \alpha$ radiation $(\lambda=1.54178 \AA$ ). Flash column chromatography was performed with silica gel (Qing Dao Ocean Chemical Factory, 300 400 mesh).

\subsubsection{Synthesis of 1-((9H-carbazol-4-yl)oxy)-3-(4-(4-methoxyphenyl)piperazin-1-yl)propan}

$-2-o l(1)$

A mixture of 4-(oxiran-2-ylmethoxy)-9H-carbazole $(100 \mathrm{mg}, 0.44 \mathrm{mmol})$ and 1-(4-methoxyphenyl)piperazine (126.8 $\mathrm{mg}, 0.66 \mathrm{mmol})$ in methanol $(10 \mathrm{ml})$ was refluxed for $2 \mathrm{~h}$. When the reaction was complete, as indicated by TLC, the solvent was evaporated under reduced pressure. The residue was purified by silica gel column chromatography (petroleum ether/ethyl acetate $=5 / 1, \mathrm{v} / \mathrm{v})$ to give the desired compound $1(119.5 \mathrm{mg}, 63 \%$ yield $)$ as a white solid. m.p. 202-204 ${ }^{\circ} \mathrm{C} .{ }^{1} \mathrm{H}$ NMR $\left(500 \mathrm{MHz}, \mathrm{DMSO}-d_{6}\right) \delta 11.23(\mathrm{~s}, 1 \mathrm{H}), 8.25(\mathrm{~d}, J=7.7 \mathrm{~Hz}, 1 \mathrm{H}), 7.44(\mathrm{~d}, J$ $=8.0 \mathrm{~Hz}, 1 \mathrm{H}), 7.33(\mathrm{t}, J=7.3 \mathrm{~Hz}, 1 \mathrm{H}), 7.28(\mathrm{t}, J=8.0 \mathrm{~Hz}, 1 \mathrm{H}), 7.14(\mathrm{t}, J=7.4 \mathrm{~Hz}, 1 \mathrm{H}), 7.07(\mathrm{~d}, J$ $=8.0 \mathrm{~Hz}, 1 \mathrm{H}), 6.86(\mathrm{~d}, J=9.1 \mathrm{~Hz}, 2 \mathrm{H}), 6.79(\mathrm{~d}, J=9.1 \mathrm{~Hz}, 2 \mathrm{H}), 6.69(\mathrm{~d}, J=7.9 \mathrm{~Hz}, 1 \mathrm{H}), 5.02(\mathrm{~d}$, $J=3.4 \mathrm{~Hz}, 1 \mathrm{H}), 4.37-4.00(\mathrm{~m}, 3 \mathrm{H}), 3.66(\mathrm{~s}, 3 \mathrm{H}), 3.00(\mathrm{t}, J=4.4 \mathrm{~Hz}, 4 \mathrm{H}), 2.77-2.53(\mathrm{~m}, 6 \mathrm{H}) .{ }^{13} \mathrm{C}$ NMR (126 MHz, DMSO- $\left.d_{6}\right) \delta 155.52,153.32,145.96,141.61,139.41,126.99,125.02,123.03$, 122.25, 119.05, 117.76, 114.72, 112.10, 110.85, 104.32, 100.96, 71.29, 67.31, 61.84, 55.66, 54.17, 50.16. Anal. Calc. for $\mathrm{C}_{26} \mathrm{H}_{29} \mathrm{~N}_{3} \mathrm{O}_{3}$ : C, 72.30; H, 6.72;N, 9.73. Found: C, 72.23; H, 6.74; N, 9.59. 
propan-2-ol (2)

A mixture of 4-(oxiran-2-ylmethoxy)-9H-carbazole $(100 \mathrm{mg}, 0.44 \mathrm{mmol})$ and 1-(2,5-dimethoxyphenyl)piperazine $(146.6 \mathrm{mg}, 0.66 \mathrm{mmol})$ in methanol $(10 \mathrm{ml})$ was refluxed for $2 \mathrm{~h}$. When the reaction was complete, as indicated by TLC, the mixture was concentrated under reduced pressure, and purified by silica gel column chromatography eluting with petroleum ether/ethyl acetate (5/1, v/v) to afford compound 2 (101.5 mg, 50\% yield). m.p. $162-164{ }^{\circ} \mathrm{C} .{ }^{1} \mathrm{H}$ NMR (500 MHz, DMSO- $\left.d_{6}\right) \delta 11.24(\mathrm{~s}, 1 \mathrm{H}), 8.26(\mathrm{~d}, J=7.8 \mathrm{~Hz}, 1 \mathrm{H}), 7.45(\mathrm{~d}, J=8.0 \mathrm{~Hz}, 1 \mathrm{H})$, $7.37-7.32(\mathrm{~m}, 1 \mathrm{H}), 7.30$ (t, $J=8.0 \mathrm{~Hz}, 1 \mathrm{H}), 7.15(\mathrm{t}, J=7.4 \mathrm{~Hz}, 1 \mathrm{H}), 7.07(\mathrm{~d}, J=8.0 \mathrm{~Hz}, 1 \mathrm{H})$, $6.81(\mathrm{~d}, J=8.7 \mathrm{~Hz}, 1 \mathrm{H}), 6.70(\mathrm{~d}, J=7.9 \mathrm{~Hz}, 1 \mathrm{H}), 6.46(\mathrm{dd}, J=8.7,2.9 \mathrm{~Hz}, 1 \mathrm{H}), 6.43(\mathrm{~d}, J=2.9$ $\mathrm{Hz}, 1 \mathrm{H}), 5.01(\mathrm{~d}, J=4.5 \mathrm{~Hz}, 1 \mathrm{H}), 4.57-3.93(\mathrm{~m}, 3 \mathrm{H}), 3.71(\mathrm{~s}, 3 \mathrm{H}), 3.67(\mathrm{~s}, 3 \mathrm{H}), 2.98(\mathrm{~s}, 4 \mathrm{H})$, $2.78-2.53(\mathrm{~m}, 6 \mathrm{H}) .{ }^{13} \mathrm{C}$ NMR (126 MHz, DMSO- $\left.d_{6}\right) \delta 155.00,153.75,146.16,142.34,141.08$, $138.88,126.47,124.50,122.51,121.73,118.52,112.98,111.57,110.32,105.44,105.08,103.78$, 100.43, 70.79, 66.73, 61.41, 55.88, 55.13, 53.79, 49.95. Anal. Calc. for $\mathrm{C}_{27} \mathrm{H}_{31} \mathrm{~N}_{3} \mathrm{O}_{4}: \mathrm{C}, 70.20 ; \mathrm{H}$, 6.72; N, 9.10. Found: C, 70.33; H, 6.70; N, 9.03.

\subsection{X-ray Crystallography}

Suitable crystals were obtained by slowly evaporating a mixture of dichloromethane and n-hexane solution at ambient temperature. Colorless crystals were mounted on a thin glass fiber in a random orientation. The data were collected by a R-AXIS RAPID II diffractometer equipped with graphite-monochromatic $\mathrm{Cu} \mathrm{K} \alpha$ radiation $(\lambda=1.54178 \AA$ ) by using a $\omega$ scan mode. The structures were solved by direct methods using Olex 2 software $^{24}$, and the non-hydrogen atoms were located from the trial structure and then refined anisotropically with SHELXL-2014 ${ }^{25}$ using a full-matrix least squares procedure based on $F^{2}$. The weighted $R$ factor, $w R$ and goodness-of-fit $S$ values were obtained based on $F^{2}$. The hydrogen atom positions were fixed geometrically at the calculated distances and allowed to ride on their parent atoms. Crystallographic data for the structure reported in this paper have been deposited at the Cambridge Crystallographic Data Center and allocated with the deposition numbers: CCDC 1032470 and 1028230 for compounds 1 and 2 , respectively.

\subsection{Tissue functional assays in vitro}

Isolated thoracic aorta rings, spleen and vas deferens of adult mature rats (Sprague-Dawley strain, 200-350g) were used to test antagonistic activities of investigated compounds ( $\mathbf{1}$ and $\mathbf{2}$ ) for $\alpha_{1 \mathrm{D}}, \alpha_{1 \mathrm{~B}}, \alpha_{1 \mathrm{~A}}$ subtype, respectively. These tissues were dissected and placed into Krebs-Henseleit solution $\left(\mathrm{NaCl} 119 \mathrm{mM}, \mathrm{KCl} 4.7 \mathrm{mM}, \mathrm{CaCl}_{2} 1.9 \mathrm{mM}, \mathrm{MgSO}_{4} 1.2 \mathrm{mM}, \mathrm{KH}_{2} \mathrm{PO}_{4} 1.2 \mathrm{mM}\right.$, $\mathrm{NaHCO}_{3} 25 \mathrm{mM}$, glucose $11 \mathrm{mM}$, EDTA $0.05 \mathrm{mM}, \mathrm{pH} 7.4$ ) at temperature $37{ }^{\circ} \mathrm{C}$ and $\mathrm{pH} 7.4$ with constant oxygenation $\left(\mathrm{O}_{2} / \mathrm{CO}_{2}, 19: 1\right){ }^{20}$

The thoracic aorta rings (approximately 4-mm long) were subjected to an optimal tension and allowed to equilibrate for $1.5 \mathrm{~h}$. Then, noradrenaline (NA $1 \mathrm{mM}$ ) were added into stimulate three times, and washed until the contractile response had become constant. The tissues were incubated with antagonists for $0.5 \mathrm{~h}$. Concentration-response curves of NA were measured at an interval of $1 \mathrm{~h}$ in the absence and presence of antagonists. To block alpha2- and beta-adrenoceptors, the experiments were conducted in the continuous presence of yohimbine $(0.1 \mathrm{mM})$ and propranolol $(1 \mathrm{mM})$. The other two tissues were performed the similar experimental protocols.

Concentration-response curves were analyzed using GraphPad Prism 5.0 software (GraphPad 
Software Inc., San Diego, CA, USA). ${ }^{26}$ As the reference of the maximal NA effect $\left(E_{\max }=100 \%\right)$ obtained before incubation with the tested compounds, contractile responses to antagonists are expressed as a percentage. The data are the means \pm SEM of at least 5 separate experiments, and the final $\mathrm{pA}_{2}$ values are obtained from the linear regression of Schild plot. ${ }^{27}$

\subsection{Homology modeling and molecular docking}

The amino acidic sequences of the human $\alpha_{1 \mathrm{~A}}, \alpha_{1 \mathrm{~B}}, \alpha_{1 \mathrm{D}}$ receptor were retrieved from SwissProt database (entry code P35348, ADA1A_HUMAN; P35368, ADA1B_HUMAN; P25100, ADA1D_HUMAN). The homology models of $\alpha_{1 \mathrm{~A}}$ and $\alpha_{1 \mathrm{~B}}$ receptors were generated due to our previously reported methods. ${ }^{6,28}$ To construct $\alpha_{1 \mathrm{D}}$ model, BlastP of $\alpha_{1 \mathrm{D}}$ sequence against Protein Data Bank (PDB) in combination with UCSF Chimera 1.10.2 package was performed to search a suitable template. ${ }^{29}$ The protein structures (PDB: 3SN6, 2R4R, 2RH1, 4XEE) with high E values, scores, and wide coverages were selected as best suitable templates (Figure 7), and the sequence identity with alpha 1D was $41.80 \%$ for $3 \mathrm{SN} 6,41.80 \%$ for $2 \mathrm{R} 4 \mathrm{R}, 38.31 \%$ for $2 \mathrm{RH} 1$ and $25.63 \%$ for $4 \mathrm{XEE}$, respectively. The homology model of $\alpha_{1 \mathrm{D}}$ subtype was generated by using the program Modeller 9.10 (all parameters were left at the default values). ${ }^{30}$ The model was then submitted to be energy optimization by using CHARMMing program. Structural evaluation and stereochemical analyses were performed using PROCHECK, PROVE, CRYST and Ramchandran plot. ${ }^{31}$ PyMOL software was employed for checking and validating protein structures after model refinement.

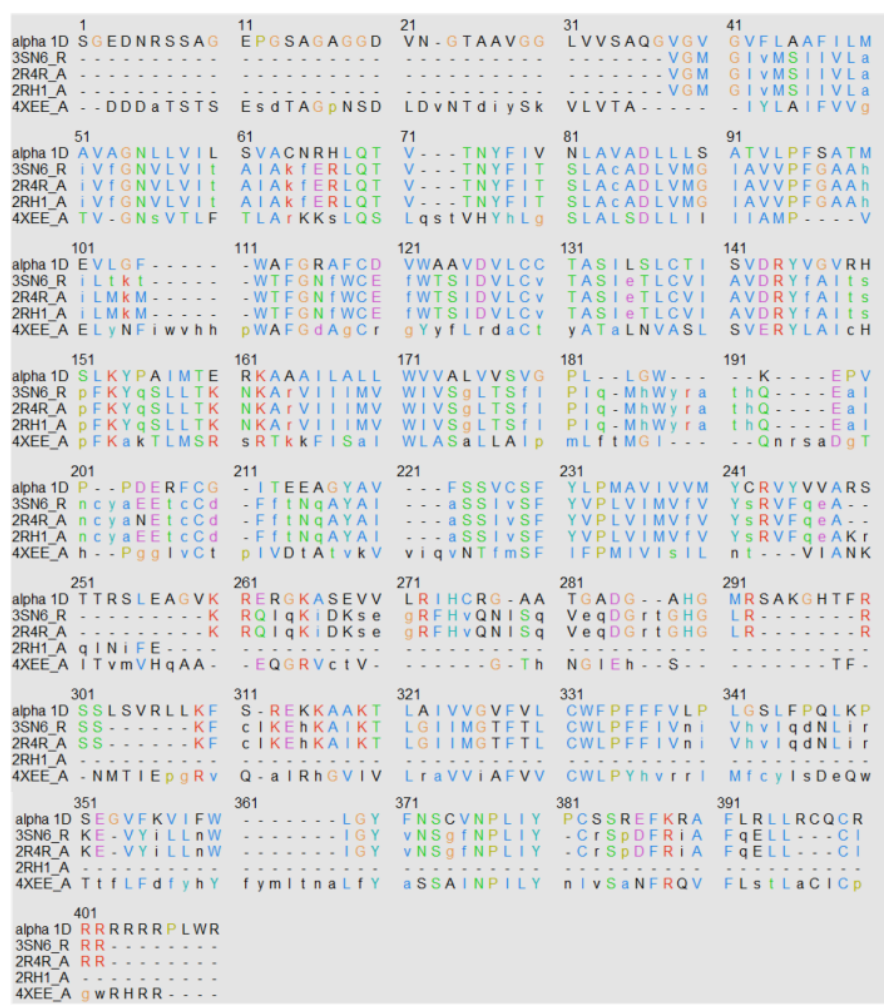

Figure 7. Amino acid sequence alignments of 3SN6, 2R4R, 2RH1, 4XEE with Alpha 1D.

Conformation $\mathrm{A}$ in the crystallographic asymmetric unit of compound $\mathbf{1}$ was subject to molecular docking studies based on the comparison of the geometrical parameters between calculated model and crystal structure. Stable conformation of compound 2 extracted from the crystal structures was saved in mol 2 format. The preparation of the pdbqt files was done by 
standard procedure using AutoDock Tools 1.5.6. ${ }^{32}$ The docking procedures were performed in AutoDock Vina using the default scorning function. ${ }^{33}$ The binding site was identified according to previous studies. ${ }^{6}$ Exhaustiveness was set to 100 , and number of output conformations was set to 20. The searching seed was random. The calculated geometries were ranked in terms of free energy of binding and the best poses were selected for further analysis.

\section{Acknowledgments}

This work was supported by grants from the National Science Foundation of Guangdong Province (No. S2013040014088), the Postdoctoral Science Foundation of Guangzhou City (Q188) and partially supported by the Guangdong Major Scientific and Technological Special Project for New Drug Development (2013A022100029).

\section{References}

1. Sarswat, A.; Kumar, R.; Kumar, L.; Lal, N.; Sharma, S.; Prabhakar, Y. S.; Pandey, S. K.; Lal, J.; Verma, V.; Jain, A.; Maikhuri, J.P.; Dalela, D.; Gupta, G.; Sharma, V. L. J. Med. Chem. 2011, 54, 302.

2. Meyer, M. D.; Altenbach, R. J.; Bai, H.; Basha, F. Z.; Carroll, W.A.; Kerwin, J. F.JJr, Lebold, S. A.; Lee, E.; Pratt, J. K.; Sippy, K. B.; Tietje, K.; Wendt, M. D.; Brune, M. E.; Buckner, S. A.; Hancock, A. A.; Drizin, I. J. Med. Chem. 2001, 44, 1971.

3. Nanda, K.; Naruganahalli, K. S.; Gupta, S.; Malhotra, S.; Tiwari, A.; Hegde, L. G.; Jain, S.; Sinha, N.; Gupta, J. B.; Chugh, A.; Anand, N.; Ray, A. Eur. J. Pharmacol. 2009, 607, 213.

4. Kinsella, G. K.; Rozas, I.; Watson, G. W. J. Med. Chem. 2006, 49, 501.

5. Ventura, S.; Oliver, V.; White, C. W.; Xie, J. H.; Haynes, J.M.; Exintaris, B. Br. J. Pharmacol. 2011, 163, 891.

6. Xu, W.; Huang, J. J.; Shao, B.H.; Xu, X. J.; Jiang, R. W.; Yuan, M. Molecules 2015, 20, 19674.

7. Jin, J.; Wang, X.B.; Kong, L. Y. Bioorg. Med. Chem. Lett. 2011, 21, 909.

8. Abou-Seri, S. M.; Abouzid, K.; Abou El Ella, D. A. Eur. J. Med. Chem. 2011, 46, 647.

9. Zaręba, P.; Dudek, M.; Lustyk, K.; Siwek, A.; Starowicz, G.; Bednarski, M.; Nowiński, L.; Raźny, K.; Sapa, J.; Malawska, B.; Kulig, K. Bioorg. Med. Chem. 2015, 23, 2104.

10. Strappaghetti, G.; Mastrini, L.; Lucacchini, A. Bioorg. Med. Chem. 2008, 18, 5140.

11. Handzlik, J.;Szymańska, E.; Wójcik, R.; Dela, A.; Jastrzębska-Więsek, M.; Karolak-Wojciechowska, J.; Fruziński, A.; Siwek, A.; Filipek, B.; Kieć-Kononowicz K. Bioorg. Med. Chem. 2012, 20, 4245.

12. Handzlik, J.; Szymańska, E.; Wójcik, R.; Dela, A.; Jastrzębska-Więsek, M.; Karolak-Wojciechowska, J.; Fruziński, A.; Zylewski, M. Med. Chem. 2014, 10, 144.

13. Castiglione, F.; Benigni, F.; Briganti, A.; Salonia, A.; Villa, L.; Nini, A.; Di Trapani, E.; Capitanio, U.; Hedlund, P.; Montorsi, F. Curr. Med. Res. Opin. 2014, 30, 719.

14. Zimmermann, K.; Sang, X.; Mastalerz, H. A. Bioorg. Med. Chem. Lett. 2015, 25, 2809.

15. Akrami, H.; Mirjalili, B. F.; Khoobi, M.; Moradi, A.; Nadri, H.; Emami, S.; Foroumadi, A.; Vosooghi. M.; Shafiee, A. Arch Pharm (Weinheim) 2015, 348, 366. 
16. Chen, Y.; Tang, C.; Wu, Y. Org. Biomol. Chem. 2015, 13, 6773.

17. Kim, Y.; Yeom, M.; Tae, J.; Rhim, H.; Choo, H. Eur. J. Med. Chem. 2016, 110, 302.

18. MacDougall, I. J.; Griffith, R. J. Mol. Graph. Model 2006, 25, 146.

19. Kossakowski, J.; Pakosinska-Parys, M.; Struga, M.; Dybala, I.; Koziol, A. E.; Collu, D.; Loddo, R. Molecules 2009, 14, 5189.

20. Handzlik, J.; Bojarski, A. J.; Satała, G. Eur. J. Med. Chem. 2014, 78, 324.

21. Huang, J.; He, F.; Huang, M.; Liu, X.; Xiong, Y.; Huang, Y.; Zhu, L.; Yang, Y.; Xu, X.; Yuan, M. Eur. J. Med. Chem. 2015, 96, 83.

22. Goldfeld, D. A.; Zhu, K.; Beuming, T.; Friesner, R. A. Proc. Natl. Acad. Sci. USA 2011, 108, 8275 .

23. de Graaf, C.; Foata, N.; Engkvist, O. Proteins 2008, 71, 599.

24. Dolomanov, O. V.; Bourhis, L. J.; Gildea, R. J. J. Appl. Cryst. 2009, 42, 339.

25. Kratzert, D.; Holstein, J. J.; Krossing, I. J. Appl. Crystallogr. 2015, 48, 933.

26. Handzlik, J.; Maciag, D.; Kubacka, M.; Mogilski, S.; Filipek, B.; Stadnicka, K.; Kieć-Kononowicz, K. Bioorg. Med. Chem. 2008, 16, 5982.

27. Nirogi, R. V.; Bandyala, T.R.; Reballi, V. J. Enzyme. Inhib. Med. Chem. 2015, $30,85$.

28. Xu, W.; Shao, B. H.; Xu, X. J.; Yuan M. J. Mol. Struct. 2016, 1106, 485.

29. Nettles, J. H.; Stanton, R. A.; Broyde, J.; Amblard, F.; Zhang, H.; Zhou, L.; Shi, J.; McBrayer, T. R.; Whitaker, T.; Coats, S. J.; Kohler, J. J.; Schinazi, R. F. J. Med. Chem. 2014, 57, 10031.

30. Yrjölä, S.; Parkkari, T.; Navia-Paldanius, D.; Laitinen, T.; Adusei-Mensah, F.; Savinainen, J. R.; Laitinen, J. T.; Poso, A.; Alexander, A.; Penman, J.; Stott, L.; Anskat, M.; Irving, A. J.; Nevalainen, T. J. Eur. J. Med. Chem. 2016, 107, 119.

31. Sashidhara, K. V.; Avula, S. R.; Doharey, P. K.; Singh, L. R.; Balaramnavar, V. M.; Gupta, J.; Misra-Bhattacharya, S.; Rathaur, S.; Saxena, A. K.; Saxena, J. K. Eur. J. Med. Chem. 2015, $103,418$.

32. Luo, W.; Chen, Y.; Wang, T.; Hong, C.; Chang, L. P.; Chang, C. C.; Yang, Y. C.; Xie, S. Q.; Wang, C. J. Bioorg. Med. Chem. 2016, 24, 672.

33. Trott, O.; Olson, A. J. J. Comput. Chem. 2010, 31, 455. 


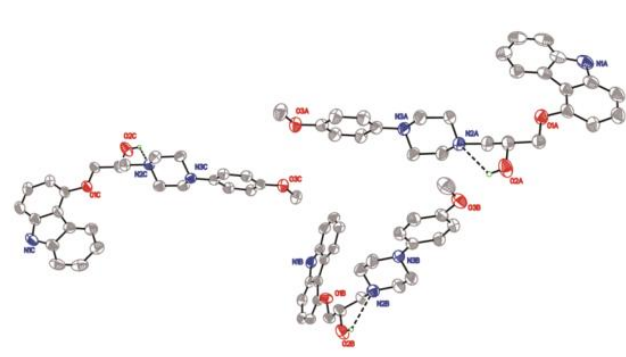

Compound 1

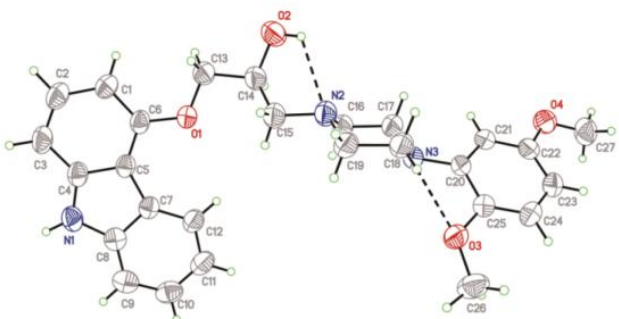

Compound 2

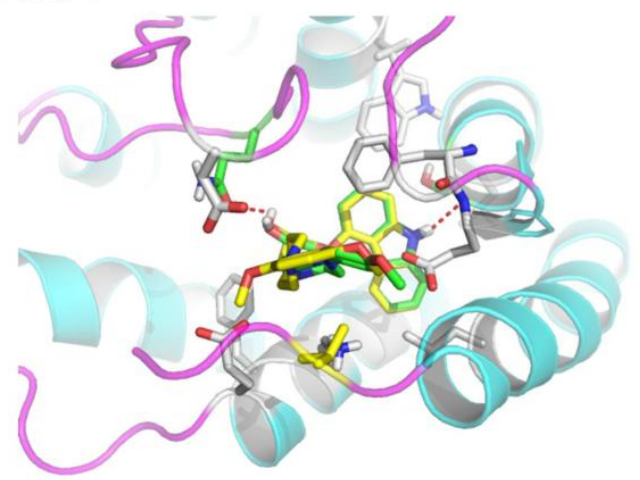

Ligands- $\alpha_{1 \mathrm{~A}}$-adrenoceptor complex

34. 